\title{
Development of Local History Learning with the Heroism Theme of K. Gholib Based on E-Book for Private Vocational School Students in Pringsewu Regency
}

\author{
Yoga Fernando Rizqi ${ }^{1}$, Djono ${ }^{2}$, Susanto ${ }^{3}$ \\ ${ }^{1}$ Magister of History Education, Universitas Sebelas Maret, Surakarta, Indonesia \\ ${ }^{2,3}$ Departement of History Education, Pascasarjana Program, Universitas Sebelas Maret, Surakarta, \\ Indonesia \\ yogafernando606@gmail.com
}

\begin{abstract}
The purpose of this research is to discuss the development of material that supports the history of the struggle of K.H Gholib, who then compiles it into an e-book using the software "Flip PDF Professional 2.4.6.8". It was developed separately to analyze the material and increase student interest in Private Vocational High Schools in Pringsewu District by instilling the values of nationalism, heroism, and patriotism of a religious figure and fighter who participated in the struggle for independence in Lampung from the attack of the Dutch Military Aggression II in 1949. The research method used was the research and development of " $R \& D$ ". The focus of e-book development uses the ADDIE development model through five intoxices, namely: analysis, design, development, implementation, and evaluation. The final results of this study show how the preparation and implementation of e-books in the classroom, so that the product developed can foster student interest in learning.
\end{abstract}

Keywords

local history; history education; heroism theme

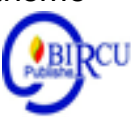

\section{Introduction}

The development of information and communication technology in the 21 st century has provided more complex challenges, such as the emergence of the phenomenon of disruption that is currently happening in Indonesia (Kurniawan, 2019: 56). This phenomenon itself is a consequence of the era of globalization. According to Wibawa \& Agustina (2019: 138), the era of globalization is characterized by mastery in every line of people's lives such as economics, politics, ideology, society, culture, and even in the world of education. Rapid change is fundamental, able to change old habits and create new habits (Widnya, 2019: 2). In this century disruption phenomenon has led to digitalization, especially in the world of education (Amirudin, 2019: 189). Classrooms will also develop with digital learning patterns that provide a more creative, participatory, diverse, and comprehensive learning experience (Rizal, 2017). According to Lestari, Mahbubah, \& Masykuri (2019: 238) the presence of digital learning in this era, has brought a change where everyone can learn to use internet networks and online classes that are more transparent, integrated and accountable. Online learning system is the implementation of education that can be used for distance learning as used in secondary education to higher education (Sobri, Nursaptini, \& Novitasari, 2020: 66). It is undeniable that most students who live in this digital age can foster enthusiasm and understanding of students when the material is delivered online (Sobron, Bayu, Rani, \& Meidawati S, 2019: 34). 
This learning phenomenon needs to be optimized for learning that is appropriate for students such as in the Vocational High School. According to (Rahmi, 2019: 105) Vocational High School education institutions, preparing students to be able to work in the field of expertise. Vocational High School Orientation is to prepare graduates who can directly work and are ready to compete in the business and industrial world with their fields of expertise or competence. This objective relates to Republic of Indonesia Government Regulation number 19 of 2005 article 26 paragraph 3 concerning how the standard of expertise possessed by graduates in Vocational High Schools is to improve their abilities, knowledge, personality, character, and expertise to develop their abilities to a higher level of education. high.

To achieve the objectives of this government regulation, schools must create a good learning system by following a predetermined curriculum. This is done to improve the quality of learning in Vocational High Schools. For this reason, digital-based learning such as electronic books or abbreviated "e-books" is the right solution. According to Fitrian \& Rohayati (2019: 13), e-books are learning resources that can improve and develop students' academic achievement compared to using textbooks. Learning to use e-books, as a source of learning can increase students' understanding of material that is more difficult and can also be used in classroom learning (Raihan S. H and Ahmadi F 2018).

According to Maimunah \& Arumi (2019: 585), electronic books "e-books" or digital books are one of the learning media that can be used in schools. This e-book, has many advantages such as not requiring large space, flexibility, functionality, lower prices compared to printed books, and easy to use (Nur Hadi Waryanto, Bambang SHM, Emut, \& Insani, 2017: 34). There are other benefits of e-books such as being able to preserve book literature, do not rot and can last a long time, have portable properties that can be used anytime and anywhere, and have several questions that can be identified when finished answering questions (Wati, 2016).

The making of this e-book is done in two ways namely directly writing a book and using software. In preparation for using the e-book, researchers used relevant data which was then converted using software. In this case, the software used is Flip PDF Professional 2.4.6.8. This software has many features that can make books in $3 \mathrm{D}$ view (Ferdianto \& Nurulfatwa, 2019). According to Seruni, Munawaroh, Kurniadewi, \& Nurjayadi, (2019: 50) Flip PDF Professional 2.4.6.8 software has many advantages, which are easy to use because it can be operated for beginners who do not know the HTML programming language. Flip PDF Professional is a feature-rich flipbook application with editing functions for pages, images, videos from YouTube, MP4, audio videos, hyperlinks, quizzes, flash, and others (Professional et al., 2019). The final product e-book that will be formed using this software, requires supporting tools such as computers, laptops / netbooks, smartphones, or tabs to open and read products (Fitrian \& Rohayati, 2019: 12).

The use of Flip PDF Professional 2.4.6.8 software, previously requires a set of materials that are ready to be formed such as books, articles, newspapers, and in the form of teaching materials that are prepared systematically. According to Trisnawati \& Sutihat (2020: 39) a collection of materials that are ready to be compiled into e-books are grouped into various forms such as handouts, books, modules, student worksheets, brochures, leaflets, books, photos / drawings, models / models. Of the various types of material that are ready to be used, researchers assume that it is necessary to develop in the context of digital media. This is also in line with the needs of students at the Vocational High School located in Pringsewu District, when conducting a preliminary study of interest in learning history, especially on local history material. 
According to Fauzi, Sunarjan, \& Amin, (2017: 39) learning local history is the study of the life of a particular community or community in the dynamic development of human life. Meanwhile, Warsino (2009) believes learning local history can increase a sense of concern and interest in their regional areas, to explore more deeply about anything that is on the past trajectory in their area. Based on these two views, the researcher seeks to foster interest in student learning at the Vocational High School in Pringsewu Regency through local history material. Local history learning that will be developed in the e-book is a religious figure who fought together in defending independence in Lampung from the attack of the Dutch Military Aggression II in 1949 named K.H Gholib. The material that will be contained in this e-book is to contain a series of events that illustrate the value of nationalism, heroism, and patriotism.

Based on the description above, by utilizing the development of information technology and communication in the 21 st century, especially in the world of education that has entered the era of digitalization. Faster changes have have created humans to work according to their fields, this is also supported by National Education in Indonesia as found in Vocational High Schools. Efforts to achieve this change will require digital-based learning in the form of e-books, especially on historical subjects with a local history of the struggle of K.H Gholib. In hopes of growing students' interest to study at Pringsewu District Private Vocational High School.

\section{Research Methods}

The research method used is Research and Development (R\&D) (Borg and Gall, 1983: 772). The focus of this research method is developing an e-book product using the steps of ADDIE model development which has five stages as follows: 1) analysis, carried out by analyzing material related to the object of research and student needs, 2) design, carried out by designing the appearance of the e-book book and content in e-books, 3) development, is done by preparing materials to be used and requires validation of media and material experts, 4) implementation is done by using limited trials and extensive trials, 5) evaluation, carried out by evaluating products that have been validated by media and material experts, and limited and extensive trials. 


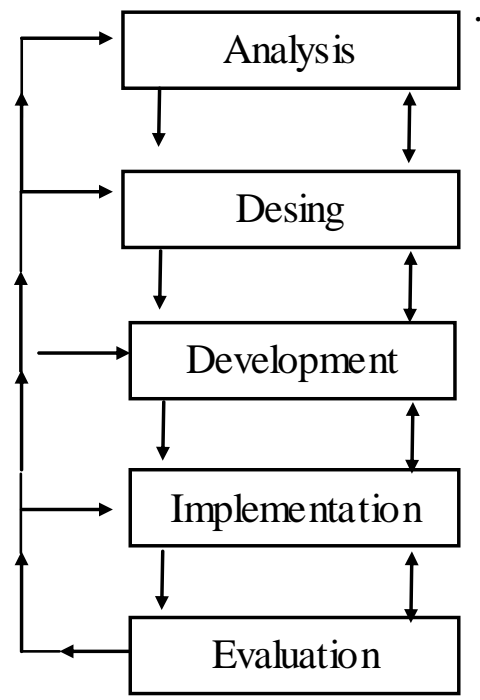

Figure 1. Five Stages of ADDIE

The Source Stages of the ADDIE Development Model (Branch, 2009)

This research was conducted at the Vocational High School in Pringsewu District, namely the K.H Ghalib Vocational High School, and the Nurul Huda Vocational High School in tenth grade students with specialization history subjects. The results of the data obtained in this study consisted of qualitative data and quantitative data. Qualitative data were obtained by distributing questionnaires about needs analysis to teachers and students. While quantitative data were obtained using 1) product development that has been validated by media and material experts, 2) implementation using limited trials and extensive trials in tenth grade, 3) evaluation is done by evaluating products that have been validated by media and material experts, their application conducted with limited trials and extensive trials to measure student interest in learning and measure student knowledge of e-book material by giving question test questions. This research uses descriptive statistical data analysis techniques. This analysis is used to process data obtained from the instrument in the form of an average questionnaire score, using the following formula: $\bar{x}=\frac{\mathbb{Z}}{N}$

Keterangan: $\overline{\mathrm{x}}$ : Average score

$\Sigma \mathrm{x}$ : The number of several items

$\mathrm{N}$ : Total number

The qualitative data obtained will be interpreted to provide meaning in decision making, using the following guidelines for evaluating conversion criteria.

Table 1. Conversion Assessment Criteria Guidelines

\begin{tabular}{|c|c|c|}
\hline Score & Interval & Category \\
\hline 5 & $4,2<\overline{\mathrm{x}}$ & Very Good \\
\hline 4 & $3,4<\overline{\mathrm{x}} \leq 4,2$ & Good \\
\hline 3 & $2,6<\overline{\mathrm{x}} \leq 3,4$ & Enough \\
\hline 2 & $1,79<\overline{\mathrm{x}} \leq 2,6$ & Less \\
\hline 1 & $\overline{\mathrm{x}} \leq 1,79$ & Very less \\
\hline
\end{tabular}

Sources of Questionnaire Average Score Analysis (Nana Sujana 2009: 109) 


\section{Results and Discussion}

\subsection{Results}

Research on the development of local history teaching materials in the struggle of KH Gholib based on e-books for private Vocational High School students of Pringsewu Regency, using the ADDIE development model developed by (Branch, 2009) by having five development steps namely analysis, design, development, implementation, and evaluation. This development model is used to produce products that aim to create an effective learning environment. The product that has been developed is expected to be used in a useful learning process with the help of Flip PDF Professional 2.4.6.8 software. The steps for developing an e-book product will be explained as follows:

\section{a. Analysis}

The analysis phase in this study was carried out in two ways: 1) distributing needs analysis questionnaires to history learning teachers and class $\mathrm{X}$ students at SMK K.H Ghalib and SMK Nurul Huda in Pringsewu District. The questionnaire was distributed by researchers in two ways namely open questionnaire and closed questionnaire. According to Sugiyono (2014), open questionnaires are questions that flow without providing limited answer choices, whereas closed questionnaires are questions that are given limited answers such as yes or no. The open questionnaire in this study was aimed at one history learning teacher in both schools, while the closed questionnaire was given to ten students with fifteen questions given to both schools with answer limits using the Guttman scale as shown in the following table:

1) Conduct interviews with history teachers in two schools, using questions that flow without guidance and are given in advance by the researcher. Furthermore, researchers also conduct literature studies relating to the object of development based on relevant research such as previous books and journals. This analysis stage uses an interactive data analysis model with Miles \& Huberman's theory (2014: 20).

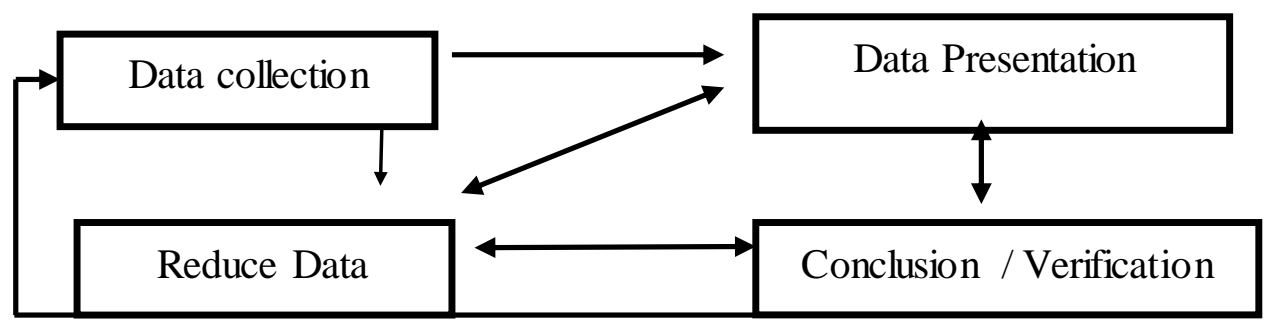

2) Give questionnaires to students in two schools, by taking a random sample of ten students by giving fifteen questions. This data analysis technique uses the Guttman scale technique with limited Yes or Unlimited answers. The explanation is as follows:

Table 2. Guttman Questionnaire Scale Question for Students

\begin{tabular}{|l|c|c|}
\hline Question & Information & Score \\
\hline Yes & $\mathrm{Y}$ & 1 \\
\hline No & $\mathrm{T}$ & 0 \\
\hline
\end{tabular}

Source: Adapted from Riduwan (2013: 16) 
Data obtained from a closed questionnaire using the Guttman scale, then the data is analyzed in statistical ways using the percentage formula (\%) as follows:

$$
P=\frac{F}{N} x 100 \%
$$

Keterangan: $\mathrm{P}=$ percentage figure

$\mathrm{F}=$ score obtained

$\mathrm{N}=$ maximum score

Data that has been measured in the next percentage will be viewed using the interpretation of student responses as follows:

Table 3. Data of Students' Response Percentage

\begin{tabular}{|l|l|}
\hline \multicolumn{1}{|c|}{ Percentage (\%) } & \multicolumn{1}{c|}{ Criteria } \\
\hline $0-20$ & Very unappealing \\
\hline $20-40$ & Not attractive \\
\hline $41-60$ & Enough \\
\hline $61-80$ & Interesting \\
\hline $81-100$ & Very interesting \\
\hline
\end{tabular}

Source: Adapted from Riduwan (2013: 15)

Table 4. Research Questionnaire for SMK K.H Ghalib Students

\begin{tabular}{|l|l|c|c|c|}
\hline Num & \multicolumn{1}{|c|}{ Question } & Yes & No & Score \\
\hline 1 & $\begin{array}{l}\text { During history learning, did the teacher ever use locally } \\
\text { loaded material? }\end{array}$ & 21 & 29 & 50 \\
\hline 2 & During history learning, did the teacher ever use e-books? & 0 & 50 & 50 \\
\hline 3 & Are you interested in learning to use e-books? & 17 & 33 & 50 \\
\hline Total & \multicolumn{3}{|c|}{ Not attractive } \\
\hline Information
\end{tabular}

Table 5. Research Questionnaire Questions for students of SMK Nurul Huda

\begin{tabular}{|l|l|c|c|c|}
\hline Num & \multicolumn{1}{|c|}{ Question } & Yes & No & Score \\
\hline 1 & $\begin{array}{l}\text { During history learning, did the teacher ever use locally } \\
\text { loaded material? }\end{array}$ & 15 & 35 & 50 \\
\hline 2 & During history learning, did the teacher ever use e-books? & 0 & 50 & 50 \\
\hline 3 & Are you interested in learning to use e-books? & 20 & 30 & 50 \\
\hline Information & \multicolumn{3}{|c|}{35} \\
\hline Information & \multicolumn{4}{|c|}{ attractive } \\
\hline
\end{tabular}

Analysis of closed questionnaire data given to students in the two schools showed the following results: for SMK K.H Ghalib scored 38: $10=38 \%$ and for SMK Nurul Huda scored 35: $10=35 \%$. Based on this preliminary research, researchers assume to develop local history learning with the theme of the struggle of K.H Gholib into an e-book product to facilitate student learning. 


\section{b. Design}

The design phase in this study is: designed to prepare learning activities that will be compiled inward. There are five design stages carried out in development based on an analysis of student need ds: 1) cover / title, 2) guidelines for using e-books, 3) table of contents, 4) learning material, 5) evaluation. In the five initial design components of making this e-book product, it cannot be separated from the Core Competencies and Basic Competencies contained in the curriculum applicable to both schools.
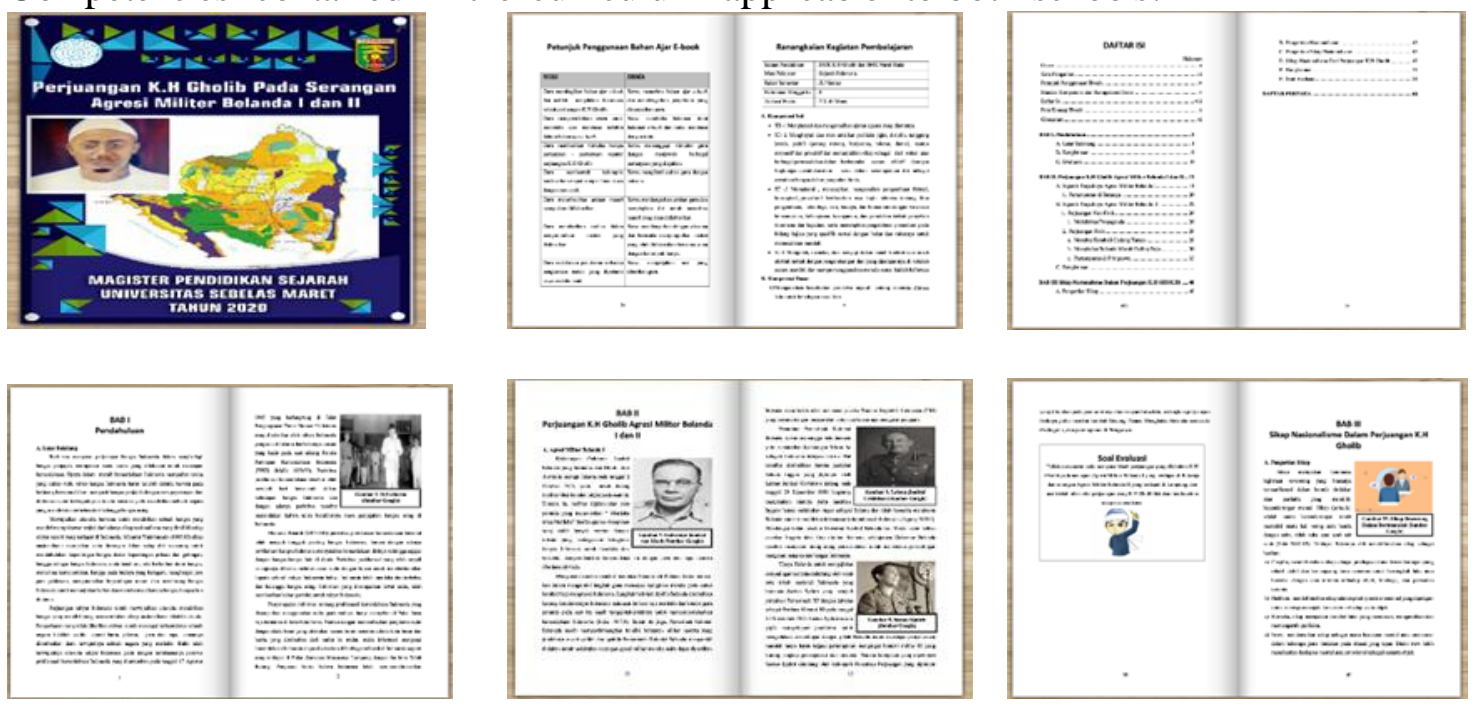

\section{c. Development}

The development phase in this research is finding and gathering various relevant sources to enrich the material, making illustrations, graphics, typing, editing, and arranging the material layout. The next activity in the development phase is the activity of validating the design of e-book product development to media and material experts. Test the validity of e-book product development made as follows:

Table 6. Evaluation of Media Expert Validity

\begin{tabular}{|c|l|c|}
\hline Num & \multicolumn{1}{|c|}{ Rated Aspect } & Score \\
\hline 1 & Cover Quality & 5 \\
\hline 2 & The Winning Design Cover & 5 \\
\hline 3 & The Accuracy of Typing Layouts & 4 \\
\hline 4 & Correct the Use of Spaces, Titles, Subtitles, Typing Material & 4 \\
\hline 5 & Completeness of Component Repair Sub Chapter & 5 \\
\hline 6 & Clarity of Material Order & 5 \\
\hline 7 & Accuracy in Chart Placement, Illustrated Image & 5 \\
\hline 8 & Clarity of Writing/Typing Total & 5 \\
\hline & Percentage Score (\%) & 38 \\
\hline & & $95 \%$ \\
\hline
\end{tabular}


Table 7. Assessment of Material Expert Validity

\begin{tabular}{|c|l|c|}
\hline Num & \multicolumn{1}{|c|}{ Rated aspect } & Score \\
\hline 1 & Conformity between the table of contents and contents of the material & 5 \\
\hline 2 & Conformity between competency standards and material & 4 \\
\hline 3 & Suitability of learning material & 4 \\
\hline 4 & Appropriate examples of illustrations given & 5 \\
\hline 5 & Good grammar suitability & 4 \\
\hline 6 & Conformity of sentences with the level of thinking of students & 5 \\
\hline 7 & Encourage students to understand the attitude of historical empathy & 5 \\
\hline 8 & Accuracy in selecting summary contents & 4 \\
\hline & Total & 36 \\
\hline & Percentage score (\%) & $90 \%$ \\
\hline
\end{tabular}

Calculation of the score results on the assessment of media and material experts using the formula:

$$
\begin{aligned}
& (V)=\text { Total validation score } \\
& \text { Maximum total score }
\end{aligned}
$$

Table 8. Validation Score Criteria

\begin{tabular}{|c|c|c|}
\hline Num & Score & Validation Criteria \\
\hline 1 & $85,01-100,00 \%$ & Very valid \\
\hline 2 & $70,01-85,00 \%$ & Valid enough \\
\hline 3 & $50,01-70,00 \%$ & Invalid \\
\hline 4 & $01,00-50,00 \%$ & Invalid \\
\hline
\end{tabular}

Source: Akbar (2013)

Based on the calculation of the formula on the results of the media validity assessment data in table 4 , the percentage of e-book product scores 38: $40=0.95 \times 100 \%$ $=95 \%$, while the data results of the material expert validity in table 5 show the percentage of e-book product scores 36: $40=0.90 \times 100 \%=90 \%$. It can be interpreted that the e-book product developed has been worth testing in local history learning with the contents of the K.H Gholib struggle material.

\section{d. Implementation}

The implementation phase in this research is carried out after the e-book product used has been declared feasible by media and material experts. Furthermore, the application of this e-book product, researchers will conduct limited and extensive trials in tenth grade at SMK K.H Ghalib and SMK Nurul Huda Kapubaten Pringsewu. Limited trial activities are conducted to measure students 'responses to the use of e-books as a facility to support learning activities, while extensive trials are conducted to measure students' interest in learning to use e-books. Explanation of implementation using limited and extensive trials will be explained as follows:

1) Limited trial, this research was conducted after one meeting in two schools with a random sample of ten students in tenth grade by giving a five-question questionnaire to test the level of e-book readability, attractiveness / response of students to the material taught using e-books. 
Table 9. Analysis of Student Responses to E-Books at SMK K.H Ghalib

\begin{tabular}{|c|c|c|c|c|c|c|}
\hline \multirow[t]{2}{*}{ Num } & \multirow[t]{2}{*}{ Question } & \multicolumn{5}{|c|}{ Assessment } \\
\hline & & 1 & 2 & 3 & 4 & 5 \\
\hline 1 & Whether the e-book design used is interesting or not & 0 & 0 & 0 & 3 & 7 \\
\hline 2 & $\begin{array}{l}\text { In your opinion whether the e-book that has been used can } \\
\text { facilitate you to learn }\end{array}$ & 0 & 0 & 0 & 2 & 8 \\
\hline 3 & $\begin{array}{l}\text { Do material illustrations in e-books, help you understand the } \\
\text { material }\end{array}$ & 0 & 0 & 0 & 1 & 9 \\
\hline 4 & By learning to use e-books, are you motivated to learn & 0 & 0 & 0 & 3 & 7 \\
\hline 5 & $\begin{array}{l}\text { Is the material contained in this e-book, easy for you to } \\
\text { understand }\end{array}$ & 0 & 0 & 0 & 2 & 8 \\
\hline \multicolumn{2}{|l|}{ total } & & & & 15 & 39 \\
\hline \multicolumn{2}{|c|}{ Total x Score } & & & & 60 & 195 \\
\hline \multicolumn{2}{|c|}{ Jumlah Total } & \multicolumn{5}{|c|}{255} \\
\hline \multicolumn{2}{|c|}{ Average } & \multicolumn{5}{|c|}{5,1} \\
\hline \multicolumn{2}{|c|}{ Information } & \multicolumn{5}{|c|}{ Very good } \\
\hline
\end{tabular}

Table 10. Analysis of Student Responses to E-Books at Nurul Huda Vocational School

\begin{tabular}{|c|c|c|c|c|c|c|}
\hline \multirow[t]{2}{*}{ Num } & \multirow[t]{2}{*}{ Question } & \multicolumn{5}{|c|}{ Assessment } \\
\hline & & \begin{tabular}{|l|l|}
1 & \\
\end{tabular} & 2 & 3 & 4 & 5 \\
\hline 1 & Whether the e-book design used is interesting or not & 0 & 0 & 0 & 2 & 8 \\
\hline 2 & $\begin{array}{l}\text { In your opinion whether the e-book that has been used can } \\
\text { facilitate you to learn }\end{array}$ & 0 & 0 & 0 & 3 & 7 \\
\hline 3 & $\begin{array}{l}\text { Do material illustrations in e-books, help you understand the } \\
\text { material }\end{array}$ & 0 & 0 & 0 & 4 & 6 \\
\hline 4 & By learning to use e-books, are you motivated to learn & 0 & 0 & 0 & 1 & 9 \\
\hline 5 & $\begin{array}{l}\text { Is the material contained in this e-book, easy for you to } \\
\text { understand }\end{array}$ & 0 & 0 & 0 & 2 & 8 \\
\hline \multicolumn{2}{|r|}{${ }^{7}$} & & & & 12 & 38 \\
\hline \multicolumn{2}{|c|}{ Total x Score } & & & & 48 & 190 \\
\hline \multicolumn{2}{|c|}{ Total number } & \multicolumn{5}{|c|}{238} \\
\hline \multicolumn{2}{|c|}{ Average } & \multicolumn{5}{|c|}{4,76} \\
\hline \multicolumn{2}{|c|}{ Information } & \multicolumn{5}{|c|}{ Very good } \\
\hline
\end{tabular}

Based on the limited test data at the first meeting held in two schools, the results show that the e-book used has drawn students' responses to learning to use e-book products specifically local history lessons with the struggle material of K.H Gholib.

2) Extensive testing, this research was conducted after four meetings in two schools with a sample of thirty students in tenth grade by giving a questionnaire to test students' interest in learning using an e-book. 
Table 11. Questionnaire Measuring Student Learning Interest in SMK K.H Ghalib

\begin{tabular}{|c|c|c|c|c|c|c|}
\hline \multirow[t]{2}{*}{ Num } & \multirow[t]{2}{*}{ Question } & \multicolumn{5}{|c|}{ The answer } \\
\hline & & SS & $\mathrm{S}$ & $\mathrm{N}$ & $\mathrm{TS}$ & STS \\
\hline 1 & $\begin{array}{l}\text { I am very interested in local history material in } \\
\text { e-books }\end{array}$ & 24 & 3 & 3 & 0 & 0 \\
\hline 2 & $\begin{array}{l}\text { I am always excited to follow the learning } \\
\text { process using e-books }\end{array}$ & 17 & 10 & 3 & 0 & 0 \\
\hline 3 & $\begin{array}{l}\text { I feel happy participating in learning activities } \\
\text { using e-books }\end{array}$ & 18 & 12 & 0 & 0 & 0 \\
\hline 4 & $\begin{array}{l}\text { I always pay attention when learning to use e- } \\
\text { books takes place }\end{array}$ & 26 & 4 & 0 & 0 & 0 \\
\hline 5 & $\begin{array}{l}\text { I always ask the teacher if I have difficulty } \\
\text { understanding e-books }\end{array}$ & 20 & 5 & 5 & 0 & 0 \\
\hline 6 & $\begin{array}{l}\text { I am very comfortable studying history using e- } \\
\text { books }\end{array}$ & 20 & 8 & 2 & 0 & 0 \\
\hline 7 & $\begin{array}{l}\text { I am always enthusiastic about learning history } \\
\text { using e-books when the teacher cannot be } \\
\text { present }\end{array}$ & 19 & 7 & 4 & 0 & 0 \\
\hline 8 & $\begin{array}{l}\text { I always understand ongoing learning using e- } \\
\text { books }\end{array}$ & 23 & 7 & 0 & 0 & 0 \\
\hline 9 & $\begin{array}{l}\text { I always work on assignments on e-book } \\
\text { material without cheating }\end{array}$ & 21 & 6 & 3 & 0 & 0 \\
\hline 10 & $\begin{array}{l}\text { I am very eager to work on assignments on e- } \\
\text { book material given by the teacher }\end{array}$ & 23 & 3 & 4 & 0 & 0 \\
\hline total & & 211 & 65 & 24 & 0 & 0 \\
\hline Total & Score & 1105 & 260 & 72 & & \\
\hline Total & Number & & & 37 & & \\
\hline Perce & tage & & & 79 & & \\
\hline Inforn & ation & & Very & tere & & \\
\hline
\end{tabular}

Table 12. Questionnaire Measuring Student Learning Interest in SMK Nurul Huda

\begin{tabular}{|l|l|c|c|c|c|c|}
\hline No & Question & \multicolumn{5}{|c|}{ The Answer } \\
\cline { 3 - 7 } & & SS & S & N & TS & STS \\
\hline 1 & $\begin{array}{l}\text { I am very interested in local history material in e- } \\
\text { books }\end{array}$ & 20 & 9 & 1 & 0 & 0 \\
\hline 2 & $\begin{array}{l}\text { I am always excited to follow the learning } \\
\text { process using e-books }\end{array}$ & 22 & 6 & 2 & 0 & 0 \\
\hline 3 & $\begin{array}{l}\text { I feel happy participating in learning activities } \\
\text { using e-books }\end{array}$ & 18 & 12 & 0 & 0 & 0 \\
\hline 4 & $\begin{array}{l}\text { I always pay attention when learning to use e- } \\
\text { books takes place }\end{array}$ & 27 & 3 & 0 & 0 & 0 \\
\hline 5 & $\begin{array}{l}\text { I always ask the teacher if I have difficulty } \\
\text { understanding e-books }\end{array}$ & 26 & 4 & 0 & 0 & 0 \\
\hline 6 & $\begin{array}{l}\text { I am very comfortable studying history using e- } \\
\text { books }\end{array}$ & 25 & 5 & 0 & 0 & 0 \\
\hline
\end{tabular}




\begin{tabular}{|l|l|c|c|c|c|c|}
\hline 7 & $\begin{array}{l}\text { I am always enthusiastic about learning history } \\
\text { using e-books when the teacher cannot be present }\end{array}$ & 25 & 5 & 0 & 0 & 0 \\
\hline 8 & $\begin{array}{l}\text { I always understand ongoing learning using e- } \\
\text { books }\end{array}$ & 25 & 4 & 1 & 0 & 0 \\
\hline 9 & $\begin{array}{l}\text { I always work on assignments on e-book material } \\
\text { without cheating }\end{array}$ & 23 & 4 & 3 & 0 & 0 \\
\hline 10 & $\begin{array}{l}\text { I am very eager to work on assignments on e- } \\
\text { book material given by the teacher }\end{array}$ & 26 & 3 & 1 & 0 & 0 \\
\hline total & 237 & 55 & 8 & 0 & 0 \\
\hline Total x Score & 1185 & 220 & 24 & \\
\hline Total Number & \multicolumn{5}{|c|}{4,76} \\
\hline Percentage & \multicolumn{3}{|c|}{ Very Interesting } \\
\hline Information
\end{tabular}

Based on extensive test data at four meetings held at two schools, the results show that the e-book used has attracted students' interest in learning to use e-book products specifically for local history lessons with the struggle material of K.H Gholib.

\subsection{Discussion}

The evaluation phase in this study was conducted to evaluate matters relating to the development of e-books. In this evaluation, four stages are carried out: (1) revising e-book products that have been developed based on suggestions and input from media and material experts, (2) e-book products that have been revised, then limited trials to measure students' responses to e-book based learning. This is done to see the feasibility of an ebook that is used as a medium of learning in the classroom, (3) after seeing students' responses, then an extensive test is conducted. This is done to implement e-book learning which is then measured based on students' interest in learning, (4) after measuring student learning interest, the next measurement is to provide questions based on e-book material. This is done to measure student knowledge based on material in e-books by giving fifteen questions. Student grades are based on question tests conducted at two schools as follows:

Table 13. The Results of the Test Questions conducted at SMK K.H Ghalib

\begin{tabular}{|c|c|c|c|c|}
\hline Num & $\begin{array}{c}\text { Answering questions } \\
\text { correctly }\end{array}$ & $\begin{array}{c}\text { Number of students who answered } \\
\text { the question correctly }\end{array}$ & Score & Category \\
\hline 1 & 11 & 5 & 73 & Good \\
\hline 2 & 12 & 3 & 80 & Good \\
\hline 3 & 13 & 4 & 86 & Very good \\
\hline 4 & 14 & 10 & 93 & Very good \\
\hline 5 & 15 & 8 & 100 & Very good \\
\hline
\end{tabular}


Table 14. The Results of the Test Questions conducted at SMK Nurul Huda

\begin{tabular}{|c|c|c|c|c|}
\hline Num & $\begin{array}{c}\text { Answering } \\
\text { questions correctly }\end{array}$ & $\begin{array}{c}\text { Number of students who answered } \\
\text { the question correctly }\end{array}$ & Score & Category \\
\hline 1 & 10 & 3 & 66 & Good \\
\hline 2 & 11 & 4 & 73 & Good \\
\hline 3 & 12 & 4 & 80 & Good \\
\hline 4 & 13 & 6 & 86 & Very good \\
\hline 5 & 14 & 8 & 93 & Very good \\
\hline 6 & 15 & 5 & 100 & Very good \\
\hline
\end{tabular}

Measurement techniques for research questions based on e-book materials are based on using the following formula:

$$
\text { Score }=\frac{\sum \text { Student Score }}{\text { Maximum Score }} \times 100
$$

Table 15. The Scale of Students' Understanding Ability Categories

\begin{tabular}{|c|c|}
\hline Score & Student Ability Category \\
\hline $81-100$ & Very good \\
\hline $61-80$ & Good \\
\hline $41-60$ & Enough \\
\hline $21-41$ & Less \\
\hline $0-20$ & Very Less \\
\hline
\end{tabular}

Source: (Arikunto, 2013: 272)

Based on the results of the evaluation of e-book products using fifteen questions to tenth grade students applied at both schools, the results show the following: for SMK KH Ghalib there are eight students in the good category and twenty-two students in the very good category, while for the SMK Nurul Huda has twelve students in the good category and eighteen students in the very good category. This can be interpreted that learning local history using e-books can attract student learning interest.

\section{Conclusion}

The development of local history learning with the theme of the struggle of K.H Gholib based on e-books, has been appropriate for use in learning. The eligibility of this ebook product is based on the assessment of media and material experts, that is, in the percentage for media $95 \%$ in the very feasible category and the percentage for the material $90 \%$ in the very feasible category. Furthermore, e-books were conducted limited trials and extensive trials in two schools namely: limited testing for SMK K.H Ghalib in percentage 5.1 in the very good category, and for SMK Nurul Huda 4.76 in the very good category. As for the extensive test for SMK K.H Ghalib in the 4.79 percentage in the very good category and for the Nurul Huda SMK in the 4.76 percentage in the very good category. After a limited and extensive trial, the researcher then measured students' knowledge by giving fifteen questions in two schools with satisfactory results. So the e-book products developed can be used for teacher and student learning. 


\section{References}

Akbar, S. 2013. Instrumen Perangkat Pembelajaran. Bandung: Remaja Rosdakarya Offset Amirudin, N. (2019). Problematika Pembelajaran Pendidikan Agama Islam di Era Digital. Prosiding Seminar Nasional PAI Dengan Pendekatan Multidisipliner, 181-192.

Arikunto, S. 2013.Prosedur Penelitian Suatu Pendekatan Praktik. Edisi Revisi. Jakarta: PT. Rineka Cipta

Fauzi, M., Sunarjan, Y., \& Amin, S. (2017). Pengembangan Bahan Ajar Berbentuk Handout Berbasis Sejarah Lokal dengan Materi Perjuangan Rakyat Banyumas Mempertahankan Kemerdekaan dalam Agresi Militer Belanda 1 Tahun 1947 Terhadap Minat Belajar Siswa Kelas XI SMA Negeri 4 Purwokerto. Indonesian Journal of History Education, 5(2), 37-43.

Fitrian, I., \& Rohayati, S. (2019). Pengembangan E-Book Berbasis Android Dengan Pendekatan Saintifik Pada Mata Pelajaran Administrasi Pajak Kelas XII Akutansi Di SMK Negeri 2 BUDURAN. Emerging Infectious Diseases, 7(1), 11-20. https://doi.org/10.1016/S0304-4017(96)01152-1

Febrianto, E. G., Djono., and Sudiyanto . 2020. The Existence of Jaranan Pogogan in Sugihwaras, Prambon, Nganjuk, Indonesia Eko Gatut Budapest International Research and Critics in Linguistics and Education (BirLE) Journal (3): 773-776.

Kurniawan, S. (2019). Tantangan Abad 21 bagi Madrasah di Indonesia. Intizar, 25(1), 5568. https $/ /$ doi.org/10.19109/intizar.v25i1.3242

Lestari, G., Mahbubah, A., \& Masykuri, M. F. (2019). Pembelajaran Bahasa Arab Digital dengan Menggunakan Media Padlet di Madrasah Aliyah Billingual Batu. Proceeding International Conference on Islamic Education (ICIED), 4(1), 238-244.

Maimunah, \& Arumi, E. R. (2019). Upaya Pengembangan Bakat Kreatifitas Bagi Siswa SMK Melalui Pembuatan E-Book INTERAKTIF. Seminar Nasional Hasil Penelitian Dan Pengabdian Pada Masyarakat IV Tahun 2019, 584-590.

Miles, Mathew B., Michael Huberman, dan Johnny Saldana. 2014. Qualitative Data Analysis-Third Edition. London: Sage Publication Ltd.

Nana Sudjana. 2009. Pengantar Statistik Pendidikan. Jakarta: PT Raja Grafindo

Nur Hadi Waryanto, Bambang SHM, K., Emut, H., \& Insani, N. (2017). Pelatihan Pembuatan Buku Elektronik Interaktif Training of Interactive Electronic Book. J. Pengabdian Masyarakat MIPA Dan Pendidikan MIPA, 1(1), 33-40.

Phillips, S. C. 2020. Education and Curriculum Reform: The Impact They Have On Learning. Budapest International Research and Critics in Linguistics and Education (BirLE) Journal (3): 1074-1082.

Rahmi, L. (2019). Perancangan E-Module Perakitan Dan Instalasi Personal Komputer Sebagai Media Pembelajaran Siswa SMK. Ta'dib, 21(2), 105-111. https://doi.org/10.31958/jt.v21 i2.1190

Riduwan. 2013. Skala Pengukuran Variabel-Variabel Penelitian. Bandung: Alfabeta

Seruni, R., Munawaroh, S., Kurniadewi, F., \& Nurjayadi, M. (2019). Pengembangan Modul Elektronik (E-Modul) Biokimia Pada Materi Metabolisme LIPID Menggunakan FLIP PDF PROFESSIONAL. Jurnal Tadris Kimiya 4, 4(1), 48-56. https://doi.org/10.15575/jtk.v4i1.4672

Sobri, M., Nursaptini, \& Novitasari, S. (2020). Mewujudkan Kemandirian Belajar Melalui Pembelajaran Berbasis Daring Diperguruan Tinggi Pada Era Industri 4.0. Jurnal Pendidikan Glasser, 4(1), 64-71.

Sobron, A. ., Bayu, Rani, \& Meidawati S. (2019). Persepsi Siswa Dalam Studi Pengaruh 
Daring Learning Terhadap Minat Belajar IPA. SCAFFOLDING: Jurnal Pendidikan Islam Dan Multikulturalisme, 1(2), 30-38.

Sugiyono. 2014. Metode Penelitian Pendidikan Pendekatan Kuantitatif, Kualitatif, dan R\&D. Bandung: Alfabeta.

Trisnawati, T., \& Sutihat. (2020). Pengembangan Bahan Ajar Handdout Dengan Pendekatan Etnomatika Berbasis Budaya Lokal Di Banten Pada Pokok Bahasan Transformasi Geometri Siswa SMA. Matrix, 1(1).

Wibawa, R. P., \& Agustina, D. R. (2019). Peran Pendidikan Berbasis Higher Order Thinking Skills (Hots) Pada Tingkat Sekolah Menengah Pertama Di Era Society 5.0 Sebagai Kemajuan Bangsa Indonesia. EQUILIBRIUM Jurnal Ilmiah Ekonomi Dan Pembelajarannya, 7(2), 137-141.

Widnya, I. K. (2019). Peran perguruan tinggi menghadapi disrupsi peradaban. Maha Widya Bhuwana, 2(1), 1-6. 